\title{
Distinct T Cell Subsets and Cytokine Production in Cultures Derived from Transformation Zone and Squamous Intraepithelial Lesion Biopsies of the Uterine Cervix
}

\begin{abstract}
Jacobs N, Renard I, Al-Saleh W, Hubert P, Doyen J, Kedzia W, Boniver J, Delvenne P. Distinct T cell subsets and Cytokine production in cultures derived from transformation zone and squamous intraepithelial lesion biopsies of the uterine cervix. AJRI 2003; 49:6-13 @ Blackwell Munksgaard, 2003
\end{abstract}

PROBLEM: The characterization of lymphocytes issued from squamous intraepithelial lesions (SIL) and from the transformation zone (TZ), where the majority of SIL occur, is important to understand the role of immunity in SIL development.

METHOD OF STUDY: We compared lymphocyte populations of the TZ and SIL with those of normal exocervix, using a technique allowing for the isolation of lymphocytes, either from the epithelium or from the underlying stroma of small biopsies.

RESULTS: The majority of cells derived from the epithelium of all biopsies were $\mathrm{CD} 8^{+} \mathrm{T}$ cells. Some SIL-derived cultures were characterized by an increased proportion of activated TCR $\gamma \delta^{+}$. The production of the immunosuppressive cytokine IL10 was significantly higher in lymphocyte cultures from the normal $\mathrm{TZ}$ in comparison with the exocervix. A decreased percentage of effector $T$ cells was observed in cultures derived from the stroma of normal TZ $\left(\mathrm{TCR} \gamma \delta^{+}\right)$or SIL $\left(\mathrm{CD}^{+}\right)$in comparison with the exocervix.

CONCLUSIONS: Our results suggest that a low proportion of effector T cells and IL10 production could contribute to the predisposition of the TZ to the development of SIL and to the progression of SIL to cervical cancer.

\section{Nathalie Jacobs ${ }^{1}$, Isabelle Renard, Walid Al-Saleh', Pascale Hubert ${ }^{1}$, Jean Doyen², Witold Kedzia ${ }^{3}$, Jacques Boniver ${ }^{1}$, and Philippe Delvenne $^{1}$}

${ }^{1}$ Department of Pathology, University of Liège, Liège, Belgium; ${ }^{2}$ Department of Gynecology, University of Liège, Liège, Belgium; ${ }^{3}$ Department of Gynecology and Obstetrics, Karol Marcinkowski School of Medicine, Poznan, Poland

Key words: IFN- $\gamma$, IL10, TCR $\gamma \delta$ T lymphocytes, uterine cervix, viral infection

Address reprint requests to Nathalie Jacobs, Department of Pathology, CHU, University of Liège, B-4000 Liège, Belgium.

E-mail: n.jacobs@ulg.ac.be

Submitted November 15, 2001;

revised January 18, 2002;

accepted February 14, 2002.

\section{INTRODUCTION}

Uterine cervix cancers represent good examples of human malignant neoplasms preceded by well characterized preneoplastic stages that are designated as squamous intraepithelial lesions (SIL). ${ }^{1}$ SIL almost exclusively develop in an area of metaplastic epithelium located at the junction between the exo- and the endo-cervix, the so-called transformation zone (TZ). ${ }^{2}$ Human papillomavirus (HPV) infection is the main etiological agent of cervical cancer. However, HPV infection is not sufficient for cancer development and the observation that these cancers are more frequent in immunodeficient women ${ }^{3,4}$ strongly suggests a role of the immune system in the outcome of HPV infections and associated (pre)cancerous lesions. Moreover, type II (IL4/IL6) or immunosuppressive (IL10) cytokines are preferentially found in the cervix ${ }^{5,6}$ and in the peripheral blood ${ }^{7,8}$ of women with SIL. In addition, the importance of activated lymphocyte infiltration in the regression of HPV-associated genital warts has been reported. ${ }^{9}$

Thus, a better characterization of the lymphocyte populations present in the TZ region (where HPV 
infection and SIL generally occur $)^{2}$ and in preneoplastic lesions is crucial to determine their implication in the protection against HPV and the development of SIL. Therefore, cervical biopsies were collected from SIL-bearing patients or from cervical lesion-free women. For each specimen, the SIL and the normal $\mathrm{TZ}$ was compared with normal exocervix of the same women. To further dissect the local immune mechanisms, we analyzed lymphocytes from epithelial and stromal tissues separately. ${ }^{10}$ For each sample, the epithelium was detached from the underlying stroma and both fragments were seeded in culture. This technique allowed us to perform phenotypic and functional studies including cytokine production of isolated lymphocytes.

\section{MATERIALS AND METHODS}

\section{Patients}

Women with a cervical SIL diagnosed by cytology and a colposcopically directed biopsy were recruited for this study. For each patient, fresh biopsies $\left(2-4 \mathrm{~mm}^{3}\right)$ of normal exocervix and SIL were obtained before any surgical procedures. In addition, we also obtained normal $\mathrm{TZ}$ and normal exocervix biopsies from women undergoing hysterectomy for other reasons than cervical pathology. These biopsies were carried out in keratinocyte culture medium (DMEM/HAMs) ${ }^{11}$ containing $100 \mathrm{U} / \mathrm{mL}$ gentamycin (Gibco, Merelbeke, Belgium) and $1.5 \mu \mathrm{g} / \mathrm{mL}$ fungizone (Gibco) and processed within a few hours. HPV DNA was analyzed in biopsy specimens by PCR with degenerated oligonucleotides hybridizing in L1 open reading frame. ${ }^{12}$ $\mathrm{HPV}^{-}$biopsies of patients with normal cervix and $\mathrm{HPV}^{+}$SIL biopsies of patients with SIL were analyzed in this work. For patients with SIL, some exocervix biopsies were $\mathrm{HPV}^{+}$. This study protocol was approved by the Ethics Committee of the Faculty of Medicine of the University of Liège.

\section{Cell Cultures}

As shown in our previous studies, ${ }^{10}$ stromal lymphocytes were grown in culture medium supplemented with IL2 alone, whereas epithelium-derived lymphocytes, which are rare in the tissue samples, had to be cultured with IL2, in the presence of a feeder layer and phytohemaglutinin (PHA).

Briefly, the biopsies were incubated in dispase II (2.4 U/mL) (Boehringer Mannheim, Brussels, Belgium) at $37^{\circ} \mathrm{C}$, with the stroma side down, for $1 \mathrm{hr}$. The epithelial sheet was then gently removed from the stroma and both tissues were washed separately. The culture medium consisted of RPMI 1640 (Gibco), supplemented with $1 \%$ non-essential amino acids
(Gibco), sodium pyruvate (1 mm) (Gibco), $100 \mathrm{U} / \mathrm{mL}$ penicillin-streptomycin (Gibco) and $1.5 \mu \mathrm{g} / \mathrm{mL}$ fungizone (Gibco). The stromal fragments were placed in 96 U-bottom microwells (Nunclon, Nunc, Denmark) with $200 \mu \mathrm{L}$ of culture medium containing human recombinant IL2 $(50 \mathrm{U} / \mathrm{mL}$, Biosource, Nivelles, Belgium). Cells migrating out of the tissue were collected every 2 days during the first 2 weeks of culture. These cells were maintained in culture with IL2 $(50 \mathrm{U} / \mathrm{mL})$ and the medium was changed twice weekly. The epithelial sheets were cultured for 2 days in U-bottom microwells with $200 \mu \mathrm{L}$ of culture medium containing IL2 $(50 \mathrm{U} / \mathrm{mL})$. On day 2 , the cells were dissociated by agitation, and depending on the size and quality of the biopsy, 2000-30,000 cells were placed in $200 \mu \mathrm{L}$ of culture medium containing IL2 $(50 \mathrm{U} / \mathrm{mL})$, PHA $(0.1 \%)$ and $10^{5}$ autologous irradiated peripheral blood mononuclear cells (PBMC). PBMC were obtained from $10 \mathrm{~mL}$ of heparinized blood, prepared by centrifugation on Lymphoprep gradients (Nycomed, Oslo, Norway) and washed three times in culture medium before irradiation, using an X-ray apparatus (Stabilivolt Siemens Berlin, Germany) (190 KV, 18 $\mathrm{mA}$, HVL: $0.5 \mathrm{~mm} \mathrm{CU}$, focal distance: $35 \mathrm{~cm}$ ) at a dose rate of $1.4 \mathrm{~Gy} / \mathrm{min}$ (total irradiation: $30 \mathrm{~Gy}$ ). Fresh medium containing only IL2 $(50 \mathrm{U} / \mathrm{mL})$ was added to the epithelium-derived cell cultures twice weekly. The origin (exocervix, TZ and SIL) of the epithelium was confirmed by Papanicolaou-stained cytospins of epithelial sheet after 2 days of culture, as previously described. ${ }^{10}$

\section{Flow Cytometry Analysis}

Double- and triple-staining were performed with fluorescent conjugated antibodies. The following monoclonal antibodies were used: anti-CD3 (SK7, PerCP), CD4 (SK3, FITC), CD8 (SK1, PerCP), CD16 (NKP15, FITC), CD19 (4G7, FITC), CD56 (MY31, PE) and TCRd (11F2, FITC) (BD Biosciences, Erembodegem, Belgium), CD25 (M-A251, PE), anti-integrin $\beta 7$ (FIB504, PE) (Pharmingen, San Diego, CA, USA), CD103 (2G5, FITC) and HLA-DR (FITC) (Immunotech, Marseille, France). The phenotype was performed on $1 \times 10^{5}-5 \times 10^{5}$ cells following standard protocols. The cells were analyzed for fluorescence intensity on a FACScan with CellQuest software (BD Biosciences).

\section{Immunohistochemical Staining}

Eight-micrometer frozen sections were fixed in $2 \%$ paraformaldehyde (UCB, Louvain, Belgium). Endogenous peroxidase was blocked with $0.2 \% \mathrm{H}_{2} \mathrm{O}_{2}$ in phosphate buffered saline PBS for $30 \mathrm{~min}$. The slides were then incubated overnight at $4^{\circ} \mathrm{C}$ with monoclonal antibodies specific for CD3 (SK7), CD8 (SK1) (BD 
Biosciences San Diego, CA, USA) and TCR $\gamma \delta(\mathrm{B} 1)$ (Pharmingen) or isotype controls in PBS with BSA $(2 \%)$ and $\mathrm{NaN}_{3}(0.1 \%)$. Biotin-labeled secondary antibodies (1/100 biotin-goat antimouse $\mathrm{IgG})$ (Vector, Burlingame, USA) (1/100 biotin-goat antirat) (Pharmingen) were applied for $30 \mathrm{~min}$ at room temperature. The slides were then incubated with avidinbiotin-HRP complex (Vectastain, ABC-HRP kit; Vector) for $30 \mathrm{~min}$ Diaminobenzidine $(0.5 \mathrm{mg} / \mathrm{mL})$ (Sigma, Bomem Belgium) was used as chromogen. Slides were counter-stained with hematoxylin and mounted for light microscopy.

Enzyme linked immunosorbent assay (ELISA) assays IL-4 and IL-10 cytokines were measured by using specific immunoassays from Pharmingen (Belgium). For IFN- $\gamma$ enzyme linked immunosorbent assay ELISA assay, antibodies from Serpine (Lattulpe Belgium) were used. Recombinant human IL-4, IL-10 and IFN- $\gamma$ were used as reference standards.

\section{Statistical Analysis}

The non-parametric Mann-Whitney or ANOVA test was applied, using Prism 2.0a software (GraphPad Software, San Diego, CA, USA).

\section{RESULTS}

Increased Proportion of TCR $\gamma \delta$ and Activated Cells $(C D 25+)$ in Some Cultures Derived from SIL Epithelium

After $20-30$ days of culture, $2 \times 10^{6}-100 \times 10^{6}$ cells were obtained for biopsy. These numbers were similar for all types of biopsies (normal exocervix, normal TZ or SIL biopsies) (data not shown). The cell phenotype is summarized in Table I. In all cultures (exocervix, TZ and SIL), more than $50 \%$ of the cells were $\mathrm{CD} 8^{+} \mathrm{T}$ cells. Few NK cells and no B cells $\left(\mathrm{CD} 19^{+}\right)$were detected. Nearly all $\mathrm{T}$ cells expressed the memory marker CD45R0 (Table I). We found less than $10 \%$ of lymphocytes expressing the activation marker CD25 (IL2 receptor) in most cases of exocervix (5/19 cultures) and $\mathrm{TZ}$ (8/10 cultures) cultures, whereas more than $30 \%$ of cells were positive for CD25 in $7 / 9$ SIL- derived cultures $(P<0.05)$ (Table I). Usually less than $10 \%$ of the cells expressed the $\operatorname{TCR} \gamma \delta$, but interestingly, in 3/5 high-grade SIL cultures, more than $40 \%$ expressed this receptor (Table I). A large portion of these cells showed an activated phenotype (CD25+) (data not shown).

To confirm the epithelial origin of the T lymphocytes, we analyzed the expression of the $\alpha \mathrm{E}(103) \beta 7$ integrin, which is preferentially expressed on intraepithelial lymphocytes. ${ }^{13,14}$ In the cultures derived from the epithelium, around $15 \%$ of cells expressed this integrin, whereas less than $2 \%$ of positive cells were detected in PBMC of the same patient (Fig. 1).
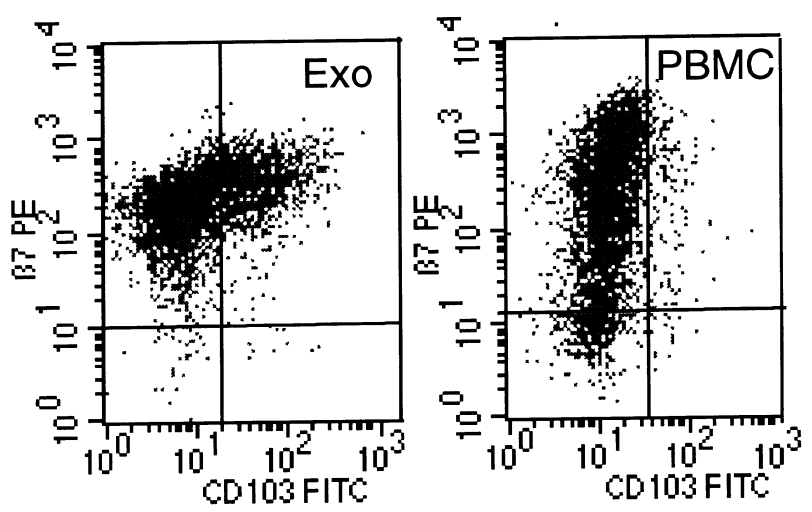

Fig. 1. Expression of the $\alpha \mathrm{E}(\mathrm{CD} 103) \beta 7$ integrin. Facs analysis of lymphocytes from exocervix epithelium derived culture (Exo) and on PBMC of the same patient with anti- $\beta 7$ PE and anti-CD103 FITC $\mathrm{mAb}$.

TABLE I. Phenotype of Lymphocytes Derived from the Epithelium

\begin{tabular}{lcccc}
\hline & Exo $_{n}{ }^{\mathrm{a}}$ & $\mathrm{TZ}^{\mathrm{a}}$ & $\mathrm{ExO}_{\mathrm{s}}{ }^{\mathrm{b}}$ & $\mathrm{SIL}^{\mathrm{b}}$ \\
\hline T cells $\left(\mathrm{CD3}^{+}\right)$ & $95 \pm 2(17)^{\mathrm{c}}$ & $93 \pm 3(17)$ & $87 \pm 6,10$ & $95 \pm 3(10)$ \\
T helper cells $\left(\mathrm{CD}^{+}\right)$ & $19 \pm 5(17)$ & $23 \pm 6(17)$ & $22 \pm 8(10)$ & $16 \pm 8(10)$ \\
T cytotoxic cells $\left(\mathrm{CD} 8^{+}\right)$ & $74 \pm 6(15)$ & $67 \pm 7(15)$ & $61 \pm 8(10)$ & $64 \pm 8(10)$ \\
TCR $\gamma \delta$ T cells & $5 \pm 2(15)$ & $7 \pm 3(15)$ & $2 \pm 2(11)$ & $24 \pm 12(11)$ \\
NK cells $\left(\mathrm{CD} 3^{-}\right.$CD56 & & $5 \pm 3(14)$ & $12 \pm 6(10)$ & $3 \pm 2(10)$ \\
B cells $\left(\mathrm{CD} 19^{+}\right)$ & $5 \pm 3(14)$ & $<1$ & $<1$ & $<1$ \\
CD45R0 & $<1$ & $>95$ & $>95$ & $>95$ \\
CD25 cells & $>95$ & $10 \pm 6(10)$ & $16 \pm 6(9)$ & $34 \pm 8(9)$ \\
\hline
\end{tabular}

${ }^{a} \mathrm{Exo}_{n}$ and $T Z=$ normal exocervix and transformation zone biopsies of patients with normal cervix.

${ }^{b}$ Exo $_{s}$ and SIL $=$ normal exocervix and SIL biopsies of patients with SIL.

${ }^{c}$ Means of cell percentage \pm S.E. of total cells after 20-30 days of culture (n) are represented. 
Increased IL10 Production in Lymphocyte Cultures Derived from the $T Z$ Epithelium

To investigate which type of cytokine is produced by $\mathrm{T}$ lymphocytes, levels of IL10 (immunosuppressive cytokine), IL4 (type II cytokine) and IFN- $\gamma$ (type I cytokine) were analyzed in the culture supernatants by ELISA (Fig. 2). Interestingly, a significantly higher production of IL10 was observed in cultures of lymphocytes derived from the $\mathrm{TZ}$ in comparison with the exocervix $(P<0.05)$. No major differences were observed in IL10 and IL4 levels between exocervix and SIL. In patients with SIL, a high amount of IL10 was detected in cultures derived from exocervix $\mathrm{HPV}^{+}$ (Fig. 2). IFN- $\gamma$, which is often produced in response to viral infection, was the only cytokine significantly expressed in cultures derived from SIL, suggesting that the production of IFN- $\gamma$ could reflect a response against HPV in some patients (Fig. 2).

Decreased Proportion of Effector T Cells in Cultures Derived from the Stroma of $T Z$ and $S I L$

To develop a model as close as possible to the in vivo situation, lymphocytes derived from the stroma were obtained in the presence of IL2 alone (without addition of PHA and autologous PBMC). Between $0.1 \times 10^{6}$ and $5 \times 10^{6}$ lymphocytes were obtained after 20-30 days of culture. The number of lymphocytes generated in cultures was similar in all types of biopsies (normal exocervix, normal TZ or SIL biopsies). After 20-30 days of culture, a lower percentage of $\mathrm{T}$ cells was obtained in stromal cultures from TZ $(P<0.05)$ and SIL $(P<0.01)$, as compared with paired normal exocervix (Fig. 3A). Most CD3- cells were CD56 ${ }^{+} \mathrm{NK}$ cells (Fig. 3A). The percentage of $\mathrm{CD}^{+}{ }^{+} \mathrm{T}$ cells did not decrease in $\mathrm{TZ}$ and SIL, as compared with exocervix cultures (Table II). However, the percentage of $\mathrm{T}$ cells with a cytotoxic potential, such as $\mathrm{CD} 8^{+} \mathrm{T}$ cells and $\mathrm{TCR} \gamma \delta^{+}$cells, was lower in SIL cultures $\left(\mathrm{TCR} \gamma \delta^{+}\right.$ cells, $P<0.01)$ and in TZ cultures $\left(\mathrm{CD} 8^{+} \mathrm{T}\right.$ cells, $P<0.01$ ) than in exocervix-derived cultures (Fig. 3B). Interestingly, patients with a high percentage of $\mathrm{TCR} \gamma \delta^{+}$cells in the epithelium-derived cultures also showed a high percentage of these cells in the stromaderived cultures.

To evaluate the number of $\mathrm{CD}^{+}$and $\mathrm{TCR} \gamma \delta^{+}$cells in vivo, immunohistochemical staining was performed on frozen biopsies. Very few $\mathrm{TCR} \gamma \delta^{+} \mathrm{T}$ cells were detected in all biopsies tested (exocervix, TZ and SIL) (data not shown). In agreement with the results obtained in vitro, a significantly lower number of $\mathrm{CD} 8^{+} \mathrm{T}$ cells were observed in the SIL underlying stroma, compared with the normal exocervix $(P<0.05)$ (Fig. 3C). The difference between exocervix and $\mathrm{TZ}$ was not significant. In parallel with FACS results, we also observed a decreased number of $\mathrm{CD}^{+}$ $\mathrm{T}$ cells in SIL versus normal exocervix, whereas the number of $\mathrm{CD}^{+}{ }^{+} \mathrm{T}$ cells was similar in both tissues (data not shown).

\section{Higher IFN- $\gamma$ Production in Cultures Derived}

from the Stroma of Patients with SIL

Cytokines were also analyzed in lymphocyte cultures derived from the stroma in the presence of IL2 alone (Fig. 4). The results were more heterogeneous than
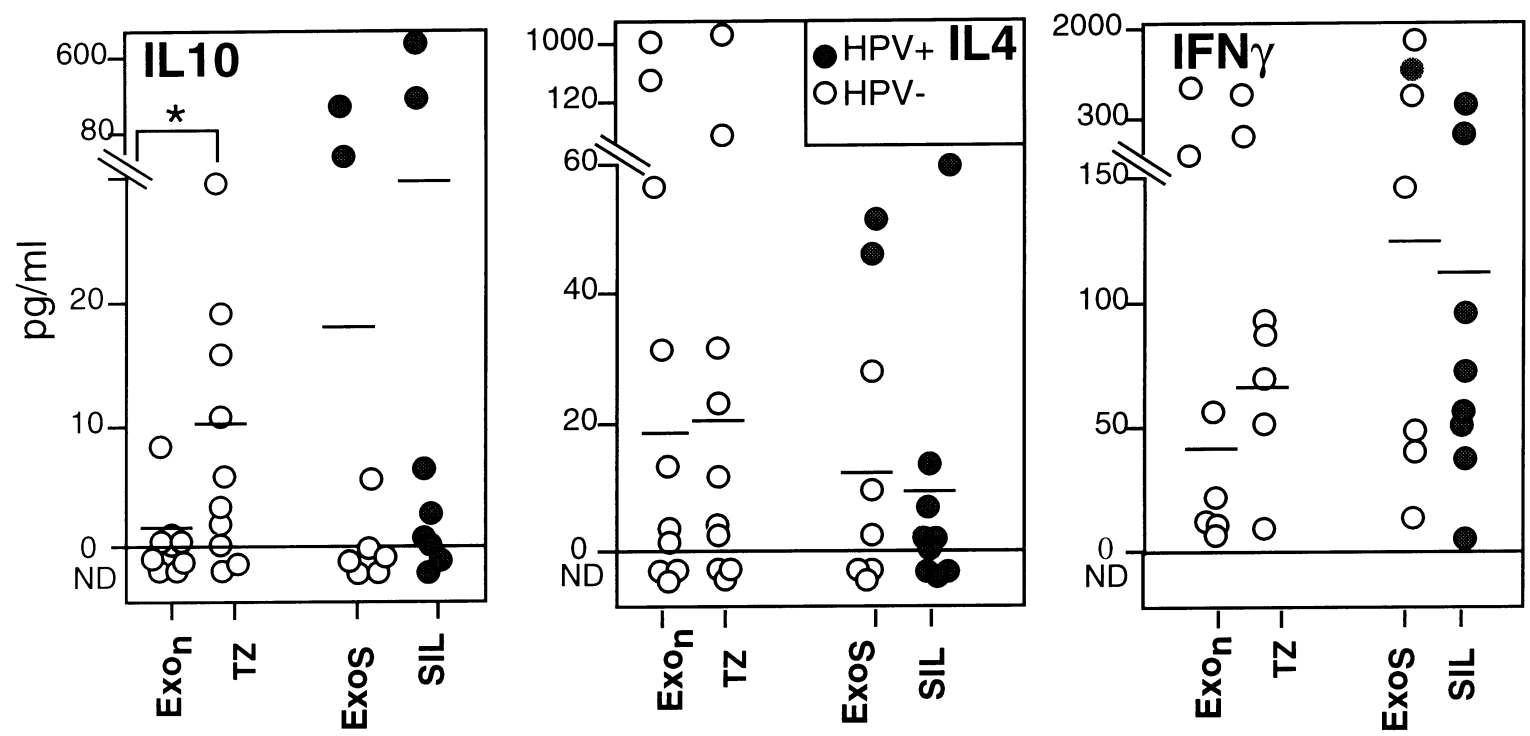

Fig. 2. Cytokine production in cultures of lymphocytes derived from the epithelium. The cytokine production was evaluated by ELISA assays and the results were reported for $1 \times 10^{6}$ cells. Each empty circle represents a biopsy $\mathrm{HPV}^{-}$and each full circle represents a biopsy $\mathrm{HPV}^{+}$. Exo ${ }_{n}$ and $\mathrm{TZ}=$ normal exocervix and transformation zone biopsies of patients with normal cervix; Exos and SIL = normal exocervix and SIL biopsies of patients with SIL; ND = undetermined, ${ }^{*} P<0.05$. 


\section{A: Flow cytometry analysis of cells}

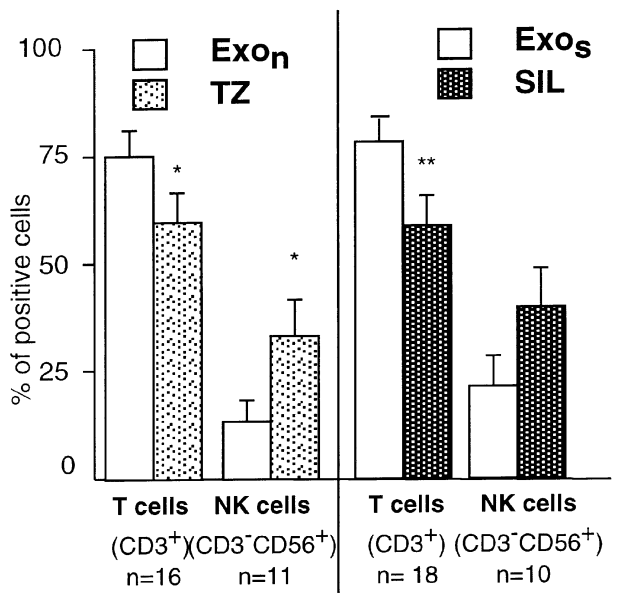

B: Flow cytometry analysis of $\mathrm{T}$ cells

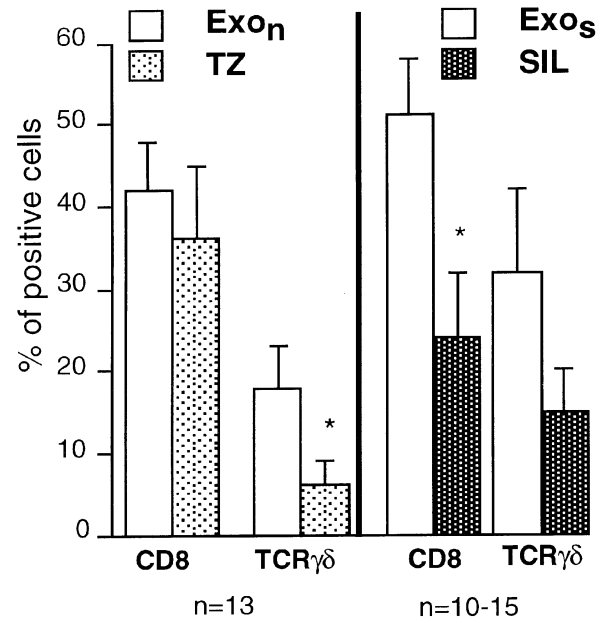

C: In situ CD8 immunostaining

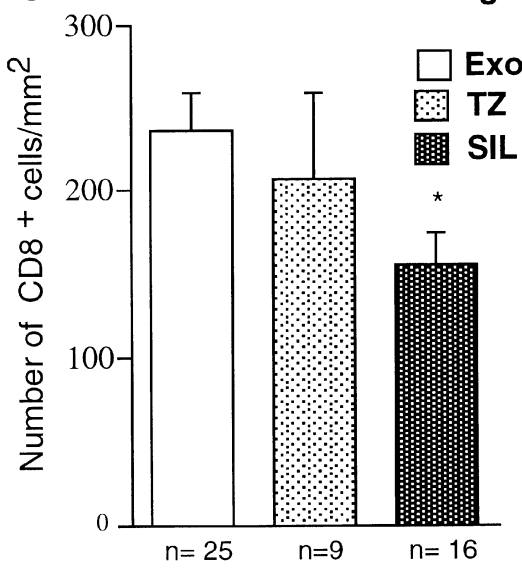

Fig. 3. Phenotype of lymphocytes derived from the stroma. (A) Exom and $\mathrm{TZ}=$ normal exocervix and transformation zone paired biopsies of patients with normal cervix; Exos and SIL $=$ normal exocervix and SIL paired biopsies of patients with SIL. (B) $\mathrm{CD}^{+}$and $\mathrm{TCR} \gamma^{+} \mathrm{T}$ lymphocytes in the stroma. Means \pm S.E. after $20-30$ days of culture are represented, ${ }^{*} P<$ $0.05, * * P<0.01$. (C) In situ CD8 immunostaining. Means \pm S.E. are represented, ${ }^{*} P<0.05$. those observed in cultures derived from the epithelium. No significant difference was detected between the exocervix versus $\mathrm{TZ}$, or between the exocervix versus SIL cultures. However, an increased production of IFN- $\gamma$ was observed in patients with SIL, in comparison with patients with normal cervix (Fig. 4).

\section{DISCUSSION}

The different immune microenvironments that we found in cervical mucosa are as follows: a higher production of the immunosuppressive cytokine IL10 in the epithelium of the TZ, a higher proportion of $\operatorname{TCR} \gamma \delta^{+}$cells in some SIL and a lower number of T cells in the stroma underlying SIL or TZ. These differences might have important consequences for the immune response decision against HPV infection and tumor development.

To the best of our knowledge, this is the first study analyzing the phenotype and functional characteristics of lymphocytes isolated either from preneoplastic lesions or from the underlying stroma. Interesting results had already been obtained with whole cervical biopsies. $^{15,16}$ To further expand these studies, we sought to discriminate the contribution of lymphocytes derived from the epithelium and from the stroma, because lymphocytes derived from whole biopsies have a mixed origin. A great majority of cells are likely to derive from the stroma since connective tissue usually constitutes the major part of the biopsies. Moreover, the density of lymphocytes is higher in the stroma, compared with the epithelium. Much attention has also been paid in this study to compare SIL with the normal exocervix and the TZ, where most cervical SIL and cancers develop. ${ }^{2}$

The majority of lymphocytes issued from the epithelium of all biopsies were $\mathrm{CD} 8^{+} \mathrm{T}$ cells, which is in agreement with a previous in situ study. ${ }^{17}$ The epithelial origin of these lymphocytes is supported by the expression of the $\alpha \mathrm{E}(\mathrm{CD} 103) \beta 7$ integrin, which has been described as a marker of intraepithelial lymphocytes. $^{13,14,18}$ Moreover, the CD103 antigen has been recently described on a discrete and stable subset of human cytotoxic $\mathrm{CD} 8{ }^{+}$cells. ${ }^{19}$ An increased number of cytotoxic cells detected in situ was previously reported during cervical tumor progression. ${ }^{20}$ As $\mathrm{TCR} \gamma \delta^{+} \mathrm{T}$ cells could also display cytotoxic functions against virus infected cells ${ }^{21}$ and skin cancer ${ }^{22}$, we also analyzed this population and demonstrated an increased percentage of these cells in high-grade SIL. The presence of $\mathrm{TCR} \gamma \delta^{+} \mathrm{T}$ cells in cervical carcinoma, ${ }^{23}$ in genital warts infected by HPV $6^{24}$ or in mice grafted with syngeneic keratinocyte expressing HPV $16^{25}$ has been previously reported. Follow-up 
TABLE II. Phenotype of Lymphocytes Derived from the Stroma

\begin{tabular}{lllll}
\hline & Exo $_{n}{ }^{a}$ & TZ $^{\mathrm{a}}$ & $\mathrm{ExO}_{s}{ }^{\mathrm{b}}$ & $\mathrm{SIL}^{\mathrm{b}}$ \\
\hline $\mathrm{CD} 6^{+} \mathrm{CD}^{-}$cells & $6 \pm 6(5)^{\mathrm{c}}$ & $4 \pm 3(5)$ & $5 \pm 5(5)$ & $3 \pm 1(3)$ \\
$\mathrm{CD} 4+\mathrm{T}$ cells & $19 \pm 5(18)$ & $14 \pm 5(18)$ & $14 \pm 5(17)$ & $22 \pm 5(17)$ \\
CD45R0 cells & $>95$ & $>95$ & $>95$ & $>95$ \\
$\mathrm{CD}^{+} 5^{+}$cells & $25 \pm 6(13)$ & $26 \pm 8(9)$ & $31 \pm 5(7)$ & $52 \pm 4(10)$ \\
\hline
\end{tabular}

${ }^{a} \mathrm{Exo}_{n}$ and $T Z=$ normal exocervix and transformation zone biopsies of patients with normal cervix.

${ }^{b}$ Exo $_{s}$ and $S I L=$ normal exocervix and SIL biopsies of patients with SIL.

${ }^{c}$ Means of cell percentage \pm S.E. after 20-30 days of culture ( $n$ ) are represented.
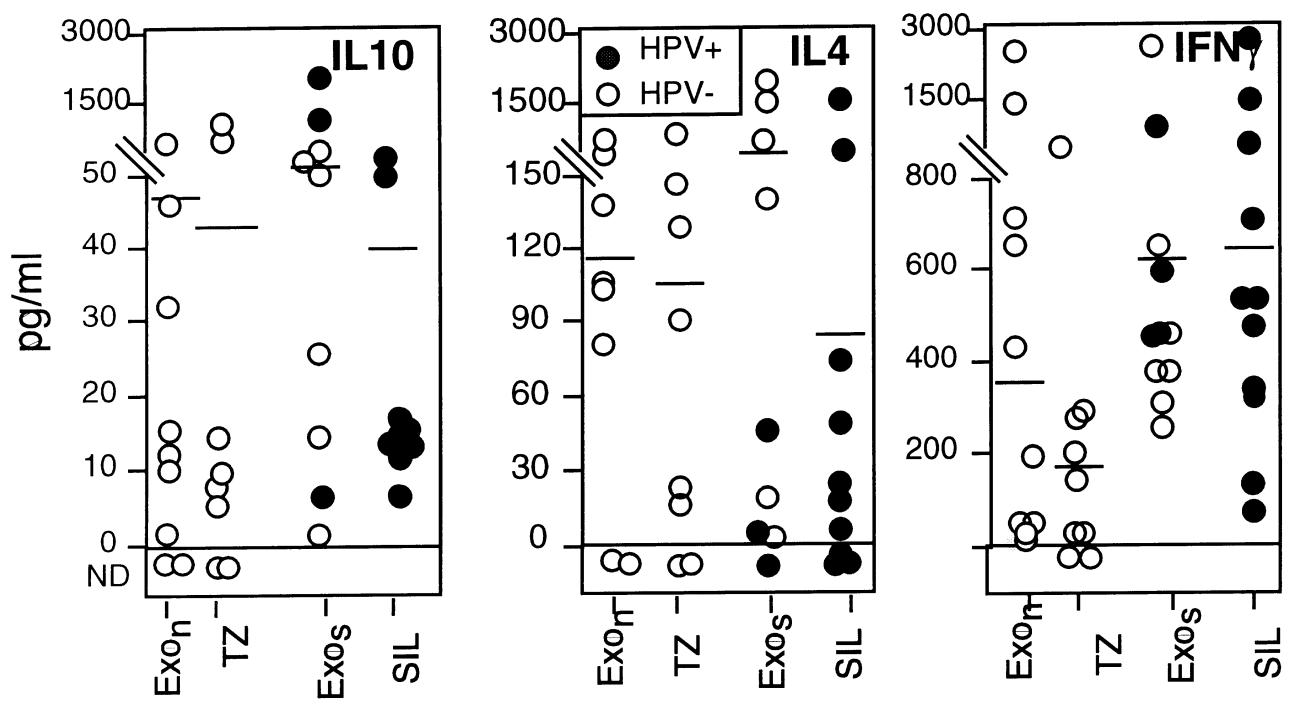

Fig. 4. Cytokine production in cultures of lymphocytes derived from the stroma. The cytokine production was evaluated by ELISA assays and the results were reported for $1 \times 10^{6}$ cells. Each empty circle represents a biopsy $\mathrm{HPV}^{-}$and each full circle represents a biopsy $\mathrm{HPV}^{+} . \mathrm{ExO}_{\mathrm{n}}$ and $\mathrm{TZ}=$ normal exocervix and transformation zone biopsies of patients with normal cervix; Exos and SIL = normal exocervix and SIL biopsies of patients with SIL; ND = not determined.

studies are needed to determine if the presence of $\mathrm{TCR} \gamma \delta^{+} \mathrm{T}$ cells is correlated with tumor protection or lesional relapse prevention. Only some $\mathrm{CD}^{+} 6^{+} \mathrm{NK}$ cells were observed in epithelium-derived cultures. This is in agreement with the study of Mc Kenzie and collaborators, showing that NK cells are usually localized in the stroma underlying SIL. ${ }^{26}$

We previously showed by RT-PCR that TZ and SIL are associated with an increased IL10 expression. ${ }^{6}$ Moreover, several studies have also reported the presence of abnormal cytokine production in cervicovaginal washings using RT-PCR or Elisa assays without determining the cytokine producing cells. ${ }^{27}$ Interestingly, in this study we showed that $\mathrm{T}$ lymphocytes from the TZ epithelium-derived cultures produced high levels of IL10, suggesting that these cells are responsible, at least partially, for the IL10 secretion in the TZ. We did not observe an increased IL10 production in cultures derived from SIL, suggesting that this cytokine is produced by tumoral keratinocytes, as already reported. ${ }^{28}$
Although generally described as an immunosuppressive cytokine, ${ }^{29-32}$ IL10 has been recently shown to enhance the cytotoxic potential of HPV-specific T cells, suggesting that this cytokine could help the immune response already established against HPV-infected keratinocytes. However, in this study, we found high levels of IL10 in the TZ before HPV infection. Furthermore, the negative effects of IL10 on antigenpresenting cells and on the induction of immune response have been demonstrated. ${ }^{32,33}$ The presence of IL10 could be linked to the lower number of antigen-presenting cells observed in TZ. ${ }^{34}$ Moreover, this IL10 production could negatively interfere with the induction of a type I immune response, which has been shown to be associated with a subsequent clearance of cervical HPV infection. ${ }^{27}$ Several hypotheses have been proposed to explain the increased sensitivity of cervical TZ to HPV infection and cancer development. ${ }^{35,36}$ Hence, a particular immune microenvironment could take place in the $\mathrm{TZ}$ and confer an increased sensitivity to HPV infection and tumor 
development. The high production of the immunosuppressive cytokine IL10 that we observed in T lymphocyte cultures derived from this region is in clear agreement with this hypothesis.

We also analyzed the lymphocyte populations derived from the stroma underlying the SIL and TZ. In these cultures, the lymphocyte phenotype was more diversified. The proportion of NK cells was more important in TZ and SIL stroma-derived cultures, as previously reported in SIL by an in situ study. ${ }^{26}$ In parallel, the percentage of $\mathrm{T}$ cells was lower in $\mathrm{TZ}$ and SIL stroma, compared with the exocervix. Interestingly, within $\mathrm{T}$ cells, the populations of cytotoxic lymphocytes were found to be under-represented in SIL $\left(\mathrm{CD} 8^{+}\right.$and $\left.\mathrm{TCR} \gamma \delta^{+}\right)$and in $\mathrm{TZ}\left(\mathrm{TCR} \gamma \delta^{+}\right)$ stroma-derived cultures. Because in a bovine model, only $\mathrm{CD} 8^{+}$and $\mathrm{TCR} \gamma \delta^{+}$lymphocytes were able to migrate into papilloma fronds, ${ }^{37}$ our results suggested the presence of a cellular immune defect in the SIL and $\mathrm{TZ}$ stroma. The lower proportion of $\mathrm{CD} 8^{+} \mathrm{T}$ cells and/or TCR $\gamma \delta^{+}$cells in cultures derived from SIL or TZ stroma could be due to a lower number of these cells in situ and/or to a proliferative defect in response to IL2. However, using immunohistochemistry, we found a quantitative reduction of $\mathrm{CD} 8^{+} \mathrm{T}$ cells in the stroma adjacent to the SIL. Very few TCR $\gamma \delta^{+} \mathrm{T}$ cells were detected in the stroma, which is consistent with a previous study. ${ }^{23}$ The difficulty of detecting TCR $\gamma \delta^{+}$ $\mathrm{T}$ cells in situ underlines the necessity to expand this important cell population by a culture method for analysis.

Despite the immune alterations described above, an immune response could take place in some patients leading to the elimination of HPV infection. As IFN- $\gamma$ production is induced in response to viral infection, the higher IFN- $\gamma$ levels in some patients with SIL could reflect an immune response against HPV. Accordingly, high amounts of IFN- $\gamma$ transcripts were associated with a good prognosis. ${ }^{38}$ Similarly, the high proportion of TCR $\gamma \delta$ cells expressing IL2 receptor (CD25) in some SIL-derived cultures could also be linked to the presence of an immune response against HPV.

In conclusion, our results suggest that quantitative and qualitative alterations of local $\mathrm{T}$ lymphocyte populations have important consequences for the development of a protective immune response in the uterine cervix. Similarities between TZ and SIL lymphocyte populations suggest that the immune alterations observed in SIL cultures are related both to modifications caused by HPV infections or associated lesions and to the particular phenotype of lymphocytes infiltrating the TZ. Studies are under investigation to better understand the role of the different lymphocyte populations in response to HPV antigens.

\section{Acknowledgments}

This work was supported by the Belgian Fund for Medical Scientific Research, the Centre de Recherche Interuniversitaire en Vaccinologie with a grant from the Walloon Region and GlaxoSmithKline and BIO4CT98-0097 contract of the EU. N. Jacobs and P. Delvenne were supported by the Belgian National Fund for Scientific Research. The authors wish to acknowledge S. Pisvin and R. Gathy for their excellent technical assistance.

\section{REFERENCES}

1. zur Hausen H: Immortalization of human cells and their malignant conversion by high risk human papillomavirus genotypes. Semin Cancer Biol 1999; 9:405-411.

2. Burghardt E, Ostor AG: Site and origin of squamous cervical cancer: a histomorphologic study. Obstet Gynecol 1983; 62:117-127.

3. Petry KU, Scheffel D, Bode U, Gabrysiak T, Köchel H, Kupsch E, Glaubitz M, Niesert S, Kühnle H, Schedel I: Cellular immunodeficiency enhances the progression of human papillomavirus-associated cervical lesions. Int J Cancer 1994; 57:836-840.

4. Ellerbrock TV, Chiasson MA, Bush TJ, Sun XW, Sawo D, Brudney K, Wright TC Jr: Incidence of cervical squamous intraepithelial lesions in HIV-infected women. JAMA 2000; 283:1031-1037.

5. Al-Saleh W, Giannini SL, Jacobs N, Moutschen M, Doyen J, Boniver J, Delvenne P: Correlation of T-helper secretory differentiation and types of antigen-presenting cells in squamous intraepithelial lesions of the uterine cervix. J Pathol 1998; 184:283-290.

6. Giannini SL, Al-Saleh W, Piron H, Jacobs N, Doyen J, Boniver J, Delvenne P: Cytokine expression in squamous intraepithelial lesions of the uterine cervix: implications for the generation of local immunosuppression. Clin Exp Immunol 1998; 113:183-189.

7. Clerici M, Merola M, Ferrario E, Trabattoni D, Villa ML, Stefanon B, Venzon DJ, Shearer GM, De Palo G, Clerici E: Cytokine production patterns in cervical intraepithelial neoplasia: association with human papillomavirus infection. J Natl Cancer Inst 1997; 89:245-250.

8. Jacobs N, Giannini SL, Doyen J, Batista A, Moutschen M, Boniver J, Delvenne P: Inverse modulation of interleukin-10 and -12 in the blood of women with preneoplastic lesion of the uterine cervix. Clin Exp Immunol 1998; 111:219-224.

9. Coleman N, Birley HDL, Renton AM, Hanna NF, Ryait BK, Byrne M, Taylor-Robinson D, Stanley MA: Immunological events in regressing genital warts. Am J Clin Pathol 1994; 102:768-774.

10. Jacobs N, Giannini SL, Al-Saleh W, Hubert P, Boniver J, Delvenne P: Generation of T lymphocytes from the epithelium and stroma of squamous pre-neoplastic lesions of the uterine cervix. J Immunol Meth 1999; 223:123-129.

11. Rheinwald JG, Green H: Serial cultivation of strains of human epidermal keratinocytes: the formation of keratinizing colonies from single cells. Cell 1975; 331:334-343. 
12. Jacobs MV, De Roda Husman AM, Van den Brule AJC, Snijders PJF, Meijer CJLM, Walboomers JMM: Groupspecific differentiation between high- and low-risk human papillomavirus genotypes by general primer-mediated PCR and two cocktails of oligonucleotide probes. J Clin Microbiol 1995; 33:901-905.

13. Cerf-Bensussan N, Begue B, Gagnon J, Meo T: The human intraepithelial lymphocyte marker HML-1 is an integrin consisting of a beta 7 subunit associated with a distinctive alpha chain. Eur J Immunol 1992; 22:273-277.

14. Roberts K, Kilshaw PJ: The mucosal $\mathrm{T}$ cell integrin alpha M290 beta 7 recognizes a ligand on mucosal epithelial cell lines. Eur J Immunol 1993; 23:1630-1635.

15. Bell MC, Edwards RP, Partridge EE, Kuykendall K, Conner W, Gore H, Turbat-Herrara E, Crowley-Nowick PA: CD8 + T lymphocytes are recruited to neoplastic cervix. J Clin Immunol 1995; 15:130-136.

16. Moscicki A-B, Hunter SD, Garland S, Quinn M, Crowe SM, Shortman K, Stittes D: A simple method for the propagation of cervical lymphocytes. Clin Diagn Lab Immunol 1995; 2:40-43.

17. Edwards RP, Kuykendall K, Crowley-Nowick P, Partridge EE, Shingleton HM, Mestecky J: T lymphocytes infiltrating advanced grades of cervical neoplasia. CD8positive cells are recruited to invasion. Cancer 1995; 76:1411-1415.

18. Cepek KL, Shaw SK, Parker CM, Russell GJ, Morrow JS, Rimm DL, Brenner MB: Adhesion between epithelial cells and T lymphocytes mediated by $\mathrm{E}$ - cadherin and the alpha E beta 7 integrin. Nature 1994; 372:190-193.

19. Hadley GA, Rostapshova EA, Gomolka DM, Taylor BM, Bartlett ST, Drachenberg CI, Weir MR: Regulation of the epithelial cell-specific integrin, CD103, by human CD8 + cytolytic T lymphocytes. Transplantation 1999; 67:1418-1425.

20. Bontkes HJ, de Gruijl TD, Walboomers JM, van den Muysenberg AJ, Gunther AW, Scheper RJ, Meijer CJ, Kummer JA. Assessment of cytotoxic T-lymphocyte phenotype using the specific markers granzyme B and TIA-1 in cervical neoplastic lesions. Br J Cancer 1997; 76:1353-1360.

21. Lehner T, Mitchell E, Bergmeier L, Singh M, Spallek R, Cranage M, Hall G, Dennis M, Villinger F, Wang Y: The role of gamma delta $\mathrm{T}$ cells in generating antiviral factors and beta-chemokines in protection against mucosal simian immunodeficiency virus infection. Eur J Immunol 2000; 30:2245-2256.

22. Girardi M, Oppenheim DE, Steele CR, Lewis JM, Glusac E, Filler R, Hobby P, Sutton B, Tigelaar RE, Hayday AC: Regulation of cutaneous malignancy by gamma delta T Cells. Science 2001; 294:605-609.

23. Hilders CG, Houbiers JG, van Ravenswaay Claasen $\mathrm{HH}$, Veldhuizen RW, Fleuren GJ: Association between HLAexpression and infiltration of immune cells in cervical carcinoma. Lab Invest 1993; 69:651-659.

24. Hong K, Greer CE, Ketter N, Van Nest G, Paliard X: Isolation and characterization of human papillomavirus type 6-specific $\mathrm{T}$ cells infiltrating genital warts. J Virol 1997; 71:6427-6432.

25. Lopez MC, Stanley MA: Cytokine profile of draining lymph node lymphocytes in mice grafted with syngeneic keratinocytes expressing human papillomavirus type 16 E7 protein. J Gen Virol 2000; 81:1175-1182.

26. McKenzie J, King A, Hare J, Fulford T, Wilson B, Stanley $\mathrm{M}$ : Immunocytochemical characterization of large granular lymphocytes in normal cervix and HPV associated disease. J Pathol 1991; 165:75-80.

27. Scott M, Stites DP, Moscicki AB: Th1 cytokine patterns in cervical human papillomavirus infection. Clin Diagn Lab Immunol 1999; 6:751-755.

28. Sheu B-C, Lin R-H, Lien H-C, Ho H-N, Hsu S-M, Huang S-C: Predominant Th2/Tc2 polarity of tumorinfiltrating lymphocytes in human cervical cancer. J Immunol 2001; 167:2972-2978.

29. Crowley-Nowick PA, Ellenberg JH, Vermund SH, Douglas SD, Holland CA, Moscicki AB: Cytokine profile in genital tract secretions from female adolescents: impact of human immunodeficiency virus, human papillomavirus, and other sexually transmitted pathogens. J Infect Dis 2000; 181:939-945.

30. Mastuda M, Salazar F, Peterson M, Masucci G, Hansson J, Pisa P, Zhang Q-J, Masucci MG, Kiessling R: Interleukin 10 pretreatment protects target cells from tumor- and allo-specific cytotoxic $\mathrm{T}$ cells and downregulates HLA class I expression. J Exp Med 1994; 180:2371-2376.

31. Buelens C, Verhasselt V, De Groote D, Thielemans K, Goldman M, Willems F: Interleukin-10 prevents the generation of dendritic cells from human peripheral blood mononuclear cells cultured with interleukin-4 and granulocyte/macrophage-colony-stimulating factor. Eur J Immunol 1997; 27:756-762.

32. Steinbrink K, Jonuleit H, Muller G, Schuler G, Knop J, Enk AH: Interleukin-10-treated human dendritic cells induce a melanoma-antigen-specific anergy in CD8 (+) T cells resulting in a failure to lyse tumor cells. Blood 1999; 93:1634-1642.

33. Peguet-Navarro J, Moulon C, Caux C, Dalbiez-Gauthier C, Banchereau J, Schmitt D: Interleukin-10 inhibits the primary allogeneic $\mathrm{T}$ cell response to human epidermal Langerhans cells. Eur J Immunol 1994; 24:884-891.

34. Al-Saleh W, Delvenne P, Arrese Estrada JE, Nikkels AF, Pierard GE, Boniver J: Inverse modulation of intraepithelial Langerhans cells and stromal macrophage populations in human papillomavirus-associated squamous intraepithelial lesions of the cervix. Virchows Arch 1995; 427:41-48.

35. Elson DA, Riley RR, Lacey A, Thordarson G, Talamantes FJ, Arbeit JM: Sensitivity of the cervical transformation zone to estrogen-induced squamous carcinogenesis. Cancer Res 2000; 60:1267-1275.

36. Moscicki AB, Burt VG, Kanowitz S, Darragh $T$, Shiboski S: The significance of squamous metaplasia in the development of low grade squamous intraepithelial lesions in young women. Cancer 1999; 85:1139-1144.

37. Knowles G, O'Neil BW, Campo MS: Phenotypical characterization of lymphocytes infiltrating regressing papillomas. J Ivirol 1996; 70:8451-8458.

38. Tartour E, Gey A, Sastre-Garau X, Lombard Surin I, Mosseri V, Fridman WH: Prognostic value of intratumoral interferon gamma messenger RNA expression in invasive cervical carcinomas (see comments). J Natl Cancer Inst; 98:287-294. 